\title{
Home bias in divestment decisions of multinational corporations in the EU
}

\author{
Laura Resmini · Giuseppe Vittucci Marzetti
}

January 30, 2020

\begin{abstract}
We empirically investigate the claim that Multinational Corporations (MNCs) suffer from a "home bias" in divestment decisions: MNCs prefer to divest from foreign subsidiaries because the "emotional involvement" and the commitment in divesting from domestic subsidiaries is larger. This issue has not been yet empirically explored in the economic literature, although it is quite recurrent in the political debate on MNCs and FDI. By using detailed company-level data on EU corporate groups during the economic crisis (2008-2014), we show that, in spite of prima facie empirical evidence of a home bias, the bias disappears when firm-, country- and sector-specific factors are accounted for.
\end{abstract}

Keywords European Union · Foreign Direct Investment · Foreign divestment · Multinational corporations

JEL Classification C21; D22; F23; G34; L25.

The data that support the findings of this study are available from Bureau Van Djik (https: //www.bvdinfo.com/). Restrictions apply to the availability of these data, which were used under license for this study. Data are available from the authors with the permission of Bureau Van Djik.

Laura Resmini

Department of Business and Law, University of Milano-Bicocca, via Bicocca degli Arcimboldi 8, 20126 Milan, Italy; CERTeT, Bocconi University, via Roentgen 1, 20136 Milan, Italy. E-mail: laura.resmini@unimib.it

Giuseppe Vittucci Marzetti

Department of Sociology and Social Research, University of Milano-Bicocca, Via Bicocca degli Arcimboldi 8, 20126 Milan, Italy, Tel.: +39-02-64487457, Fax: +39-02-64487561. E-mail: giuseppe.vittucci@unimib.it 


\section{Introduction}

The European Union (EU) is one of the most important areas in the world as a source and destination of Foreign Direct Investment (FDI). In 2007, EU FDI inflows reached the peak level of $\$ 798$ billion, about $43 \%$ of total world inflows. In the Great Recession in 2008, inflows decreased dramatically. In 2014, FDI inflows to the EU countries worth $\$ 258$ billion, accounting for $21 \%$ of the world total. Inflows fell in 18 out of 28 European countries. During the same period, inward FDI stocks in the EU countries increased on average by $1.7 \%$ per year. This notwithstanding, the EU share of inward FDI stocks fell from $40 \%$ in 2007 to $32 \%$ in 2014 (UNCTAD 2015).

Although FDI tends to reflect long-lasting interest in foreign operations, these figures suggest that divestment has been widespread; and this could raise concerns over the stability of foreign investments, especially during periods of economic turmoil. Indeed, many countries pursue active policies for attracting FDI. These policies are based on the expected benefits from foreign investment, which are supposed to bring into the country resources, technologies, knowledge and skills that domestic firms do not possess (e.g. van Pottelsberghe de la Potterie and Lichtenberg 2001; Görg and Strobl 2001; Görg and Greenaway 2004; Branstetter 2006). Clearly, these potential benefits are the more relevant, the less footloose multinational corporations (MNCs) are.

In fact, divestment decisions of foreign firms have not received the same attention as investment decisions. ${ }^{1}$ Several reasons may explain such lack of coverage. First, quantitative information is difficult to obtain, since exits are often considered as an admission of failure (McDermott 2010; Benito 1997). Secondly, the divestment decision is one of the most difficult to take: "if investment is a hopeful affair like marriage, divestment is more like divorce" (Boddewyn 1983a, p.27). It involves unpopular decisions that could damage the reputation and the image of the company both at home and in the host countries.

This notwithstanding, it is usually claimed that foreign divestment is simpler than domestic divestment, since it is more "impersonal" and "the victims are far away - both spatially and emotionally" (Boddewyn 1983a, p.31). This argument is better illustrated by considering the following anecdotes. In 2014, AB Electrolux, a leading Swedish multinational, announced its decision to restructure its production network in order to enhance efficiency by dismissing some plants. The closure decision was a choice between two production sites: one located in Schwanden (Switzerland) and the other in Mariestad (Sweden). The company eventually decided to dismiss the Swiss plant. In 1998, Siemens Semiconductors closed one of its three semiconductor plants in Europe. These plants were located in France, UK and Germany. Once again, the choice was between the UK and the German plant, and the final decision was to stop the production in the UK. ${ }^{2}$ Another interesting example is the case of Avesta Sheffield, another Swedish multinational that in 1998 decided to close a production plant in the UK and retained a production plant in Sweden (Richbell and Watts 2000). In all these cases, public opinion was

\footnotetext{
1 McDermott (2010) terms foreign divestment the "neglected area among the international business and business strategy academics" (p.37), while Norbak et al. (2015) point out that there is still a gap in the literature "about the decisions of MNCs to divest affiliates" (p.811).

2 The French plant did not enter into the decision, since it was run jointly with IBM (Richbell and Watts 2000).
} 
particularly negative, and despite the lack of strong evidence sustaining such a claim, it was believed that the decision to close down or sell the subsidiary would not have been taken had the firm being "national".

These examples hint at the existence of a possible "home bias" in divestment decisions of MNCs, i.e. the possibility that MNCs are more likely to divest production plants located abroad rather than in their own home country. And economic downturns might further exacerbate this bias, provided that it exists.

Foreign divestment has received scant attention by scholars to date, both from a theoretical and an empirical perspective. As for the former, Boddewyn (1983b) suggests that foreign divestment, i.e. "deliberate and voluntary reduction or elimination of actively controlled foreign subsidiaries and branches through sale or liquidation" (p.346), can be treated as the reverse process of foreign investment. From this perspective, the factors driving foreign divestment are the same as foreign investment, with the opposite sign, and some empirical works provide support to this "reversed theory" (Boddewyn 1979; Chen and Wu 1996; Belberdos and Zou 2006). The most important factors seem to be low profits, poor performance and low productivity, which in turn may be due to high costs, permanent decreases in demand or the entry of more efficient competitors, as well as to uncertainty, government instability and regulatory inefficiency (Berry 2013; Benito 1997, 2005; Harrigan 1981; Belberdos and Zou 2006).

Other factors also play a role. Empirical evidence suggests that the probability of divestment increases with product unrelatedness and with product and geographical diversification, whereas it decreases with age, size, market experience, the degree of integration within the group and sunk costs (Berry 2013). Subsidiaries with product lines related to the parent firm's core business may benefit from synergies that come from sharing resources, information and knowledge. Loss of control may instead arise from (geographic and productive) diversification. Thus, the further away from the core activities of the group a unit is, the less likely inter-group communication and cooperation are, and the greater the likelihood of divestment (Berry 2013).

Many scholars have confirmed the existence of a "liability of newness" (Stinchcombe 1965; Geroski 1995), i.e. a positive relationship between the firm's age and its survival probability (e.g. Freeman et al. 1983; Dunne and Hughes 1994; Carroll and Hannan 2000). ${ }^{3}$ Also smallness may generate disadvantages that increase the probability of divestment (e.g. Jovanovic 1982; Pakes and Ericson 1998; Honjo 2000; Norbak et al. 2015). Finally, multiproduct plants have better chance to survive than single product plants, because sunk costs related to the production of multiple goods reduce competition from incumbents (Bernard et al. 2007).

Despite these studies provide information about the magnitude and causes of foreign divestment, they do not help to understand whether the decision making process is similar to the one of domestic firms; ${ }^{4}$ or if there is some systematic

\footnotetext{
3 Some authors (e.g. Bruderl and Schussler 1990; Mahmood 2000) find evidence of an inverted U-shaped relationship between age and survival probability.

4 Several reasons in fact suggest the contrary. First, while most domestic firms are independent companies, foreign firms are usually part of a network. Therefore, they could exhibit greater longevity than domestic firms with similar characteristics (Mata and Portugal 2002, 2004). Secondly, MNCs are more footloose than their domestic counterparts; therefore, the probability to leave an economy, should this economy experience an economic downturn, could be higher for foreign than for domestic enterprises (Alfaro and Rodriguez-Clare 2004; Driffield and Noor
} 
difference in the way MNCs treat local vs. foreign branches in divestment decisions. Moreover, these studies adopt a one-country perspective, being it the home (Benito 2005; Berry 2013; Norbak et al. 2015) or the host country (Godart et al. 2012; Soule et al. 2014; Chen and Wu 1996). This implies that they cannot analyze foreign divestment as part of an international or regional plant network strategy of MNCs (Belberdos and Zou 2006). Another limitation is that they barely compare firms across different industries and distinguish foreign from domestic divestment. ${ }^{5}$

The aim of this paper is to investigate these issues. We analyze companies closure and exit rates within corporate groups in the EU28 during the recent economic crisis (2008-2014). Although market failures and company restructurings might occur even during economic expansions, the relative importance of the home bias, if it does exist, should be magnified in economic downturns. ${ }^{6}$

We consider corporate groups located in different EU countries and search for systematic differences in company exit rates between national and foreign subsidiaries of the same group not accounted for by firm-, industry- and countryspecific factors.

Results show that there is some prima facie empirical evidence of home bias. However, the evidence is not robust and tends to disappear when one accounts for company characteristics as well as industry and (home and host) country specific effects.

The rest of the paper is organized as follows. Section 2 presents the data, the variables and the empirical strategy. Section 3 discusses the main results. Section 4 concludes.

\section{Data description and empirical methodology}

We built up a company-level database starting from Amadeus and Orbis (Bureau Van Djik). ${ }^{7}$ We considered all the companies located in EU28 and active in 2008, and retained only those for which a Global Ultimate Owner (GUO), i.e. an independent entity whose (direct and indirect) share in the company is greater than $50 \%$, was clearly identified. Each GUO identifies a different corporate group.

1999; Görg and Strobl 2003). The poor embeddedness into host economies of foreign firms may reflect the fact that, being part of international production networks, they tend to source their production resources mainly from abroad. At the same time, they are more export-oriented than domestic firms. This implies that the local market is less important for foreign firms than for domestic ones (Godart et al. 2012). Some authors suggest that the opposite reasoning may also apply: foreign firms are less likely to exit because the sunk costs related to the activity of investing abroad are likely to be higher than those related to the settlement of a domestic plant; in order to be able to afford the burden of higher sunk costs, foreign firms need to be more productive than domestic ones (Doms and Jensen 1998; Helpman et al. 2004; Girma and Görg 2007; Godart et al. 2012).

5 Notable exceptions are Godart et al. (2012) and Norbak et al. (2015), who however adopt a one-country perspective, Ireland (host country) and Norway (home country) respectively.

6 The majority of MNCs in Europe faced poor performance and prospects, and parent companies had serious profit problems. In such a difficult situation, MNCs might have been really tempted to dismiss, ceteris paribus, a foreign rather than a domestic subsidiary in order not to further exacerbate the economic recession in their own country, thus avoiding unfavorable community and government reactions at home.

7 Restrictions apply to the availability of these data, which were used under license for this study. Data are available from the authors with the permission of Bureau Van Djik. 
Table 1 Summary statistics of the distribution of exit rates of foreign and domestic subsidiaries by MNC located in EU from 2008 to 2014

\begin{tabular}{lccc}
\hline \hline & Mean & Std.Dev. & Obs. \\
\hline Domestic subsidiaries & $0.90 \%$ & 6.90 & 11,232 \\
Foreign subsidiaries & $1.23 \%$ & 9.41 & 11,232 \\
\hline All subsidiaries & $1.06 \%$ & 5.78 & 11,232 \\
\hline \hline
\end{tabular}

For each of these companies we checked if they were still active in $2014,{ }^{8}$ and collected information on location, core and secondary businesses (4-digit NAICS 2012 classification), year of incorporation, employment, turnover, and other financial statistics from 2008 to 2014. For each of the GUOs, we collected information on the location/country of origin and, if it was a company, the sector in 2008 (2-digit NACE Rev. 2).

We ended up with 1,524,654 companies directly or indirectly owned by $1,211,894$ distinct GUOs, ${ }^{9} 11,232$ of whom own companies in more than one EU member state. We considered the latter as MNCs.

At the level of each MNC, we computed exit rates from 2008 to 2014 in domestic and foreign subsidiaries. In this respect, a company were classified as a domestic/foreign subsidiary of the corporation by comparing its location and the country of origin/location of its GUO. Exit rates in each category are computed by dividing the number of companies in the category that were active in 2008 and not active in 2014 on the total number of companies in the category in $2008 .{ }^{10}$

Table 1 shows the summary statistics of the distribution of exit rates from 2008 to 2014 computed for domestic/foreign subsidiaries of each MNC. The mean exit rate in domestic subsidiaries is $0.90 \%, 0.33$ percentage points smaller than in foreign ones $(1.23 \%)$, with a relative risk of exit for foreign subsidiaries with respect to domestic ones of 1.37 , i.e. the exit of foreign subsidiaries is 1.37 times as likely as the exit of domestic ones.

Such difference (statistically significant at the 1\%) hints at a possible "home bias" in divestment decisions of MNCs in the EU28, i.e. their preference for foreign divestment over domestic ones in economic downturns. ${ }^{11}$

A simple way to test for the presence of such bias, controlling for all the possible unobserved time-invariant factors at the MNC level, is to treat the exit rates in domestic subsidiaries and foreign subsidiaries as paired samples matched at the

\footnotetext{
8 A company is not active if in liquidation, bankruptcy, dissolved, or if no financial information has been provided for the last six years. A firm may dissolve because of a merger or take-over, a de-merger, after liquidation or at the end of the bankruptcy process. All the companies with an unknown or unclear status were dropped.

9 There were also 178,384 companies with two GUOs. Such companies have been attributed to both the GUOs.

10 To give an example, let us assume that in 2008 a certain GUO located in Germany owned 80 active companies in Germany and 200 active companies in EU outside Germany (France, UK, Italy, etc.). If, in 2014, 2 out of the 80 companies in Germany and 6 out of the 200 companies abroad were not active, the exit rates in domestic and foreign subsidiaries were, respectively, $2.5 \%$ and $3 \%$.

11 In the sample, the total number of companies classified as foreign (domestic) subsidiaries of MNCs in EU active in 2008 were 52378 (79 742), out of which 710 (927) were not active in 2014. Assuming an exit rate for foreign subsidiaries 0.3 percentage points lower entails 157 companies "closed" for the existence of such bias.
} 
GUO level. Under the null of no home bias, the sample mean of the differences of the paired data should not be statistically significant; under the alternative that sample mean should be smaller than zero. This amounts to regress the exit rate in the domestic/foreign subsidiaries $-f \in\{$ domestic, foreign $\}-$ of the $\mathrm{MNC} j, e_{j f}$, on a series of GUO dummies $\mu_{j}$ and a dummy $h_{j f}$ equal to one if the subsidiaries are domestic and zero otherwise:

$$
e_{j f}=\beta_{0}+\mu_{j}+\beta_{1} h_{j f}+\epsilon_{j f}
$$

where $\epsilon_{j f}$ is the error term, and test for the statistical significance of $\beta_{1}$.

Since exit rates are computed at the domestic/foreign level of each MNC and the number of companies over which the rates are computed is different, a rather natural set of weights is made up of this number. Equation (1) can be therefore estimated more efficiently by Weighted Least Squares (WLS), with weights equal to the number of companies over which each exit rate is computed. ${ }^{12}$

As a matter of fact, the former procedure returns a point estimate of the "home bias" equal to the following Linear Probability Model (LPM):

$$
y_{i}=\alpha_{0}+\mu_{j}+\alpha_{1} h_{i j}+\nu_{i}
$$

where $y_{i}$ is a dummy equal to 1 if the company was not active in 2014 and 0 otherwise, $\mu_{j}$ are GUO dummies, $h_{i j}$ is a dummy equal to 1 if the company and its GUO were located in the same country and 0 otherwise, and the "home bias" is given by $\alpha_{1}$.

Equation (2) also allows us to include other controls at the level of the individual company $\left(\boldsymbol{X}_{i}\right)$ and of the GUO-company paired characteristics $\left(\boldsymbol{Z}_{i j}\right)$ :

$$
y_{i}=\alpha_{0}+\mu_{j}+\alpha_{1} h_{i j}+\boldsymbol{\alpha}_{2} \boldsymbol{X}_{i}+\boldsymbol{\alpha}_{3} \boldsymbol{Z}_{i j}+\nu_{i}
$$

In line with the literature on firm exit and foreign divestment, we control for: $i$ ) country- and sector-specific factors, by including sector (2-digit level) and country dummies; ii) company-level characteristics, by including the age of the company (also squared to account for possible nonlinearities) and its size; iii) factors associated with the relation between the subsidiary and the parent company. ${ }^{13}$

As for the size, firms were classified as micro, small, medium or large on the base of their 2006-10 average employees and turnover (according to the criteria set by the European Commission in the Commission Recommendation of May 6th, 2003). We added the corresponding dummies to the regression equation. Finally, we distinguished between horizontally and vertically integrated corporate groups

\footnotetext{
12 This can be justified from a theoretical perspective if the exit equation at the level of the individual company satisfies the Gauss-Markov assumptions, so that the error term in Equation (1) has a variance proportional to the inverse of the sample size over which the rate is computed. The mean number of domestic (foreign) MNC subsidiaries in 2008 is 7.10 (4.66), with a standard deviation of 28.69 (18.11).

13 Equations (2) and (3) are estimated by OLS with heteroskedasticity-robust standard errors. In fact, although the OLS estimator is unbiased and consistent, it is inefficient. An asymptotically more efficient linear estimator can be computed as follows: i) estimate the model by OLS and obtain the fitted values $\hat{y}_{i}$; ii) bring all the fitted values into the unit interval (in particular, we set $\hat{y}_{i}=.001$ when $\left.\hat{y}_{i}<0\right)$; iii) compute the estimated variances $\hat{\sigma}_{i}=\hat{y}_{i}\left(1-\hat{y}_{i}\right)$; iv) estimate the main equation by WLS using weights $\hat{\sigma}_{i}^{-1}$ (see Wooldridge 2010, pp. 562-565). As a matter of fact, this WLS estimator in our case delivers estimates very similar to the ones produced by the OLS estimator in terms of sign, size and significance.
} 
by including a dummy equal to one if the company and its GUO operate in the same sector (horizontal relationship) and zero otherwise (vertical relationship). ${ }^{14}$

As suggested by the literature, we expect that the exit rate is higher for smaller and younger companies and for companies operating in the same sector as its GUO, since horizontal FDI is less integrated within the corporation than vertical FDI and duplicate activities already carried out by other plants.

Since we are interested in the average marginal effects, the LPM is a suitable binary response model. This notwithstanding, in order to overcome the two main limitations of the LPM (fitted probabilities not bounded between 0 and 1, and partial effect of any explanatory variable assumed to be constant), as a further robustness check we estimate the individual exit Equation (3) by running a mixedeffects probit regression (Demidenko 2004; Rabe-Hesketh and Skrondal 2012).

In particular, we estimate: i) a two-level probit model with random intercept:

$$
\operatorname{Pr}\left(y_{i j}=1 \mid h_{i j}, \boldsymbol{X}_{i}, \boldsymbol{Z}_{i j}, u_{j}\right)=\Phi\left(\gamma_{0}+\gamma_{1} h_{i j}+\boldsymbol{\gamma}_{2} \boldsymbol{X}_{i}+\gamma_{3} \boldsymbol{Z}_{i j}+u_{j}\right)
$$

where $\Phi$ is the standard normal cumulative distribution function and the random intercepts $u_{j}$ are realizations (one for each GUO $j$ ) from a normal distribution with mean 0; ii) a two-level probit model with random intercept and slope:

$$
\operatorname{Pr}\left(y_{i j}=1 \mid h_{i j}, \boldsymbol{X}_{i}, \boldsymbol{Z}_{i j}, \boldsymbol{u}_{j}\right)=\Phi\left(\gamma_{0}+\gamma_{1} h_{i j}+\boldsymbol{\gamma}_{2} \boldsymbol{X}_{i}+\boldsymbol{\gamma}_{3} \boldsymbol{Z}_{i j}+\left(1, h_{i j}\right) \boldsymbol{u}_{j}\right)
$$

where the $2 \times 1$ vector $\boldsymbol{u}_{j}$ denotes the random effects, which are realizations (one for each GUO $j$ ) from a multivariate normal distribution with mean 0 and $2 \times 2$ variance matrix $\boldsymbol{\Sigma} .{ }^{15}$ To compare the probit estimates to the LPM estimates, for both the models we compute and report the average marginal effect, or average partial effect (APE), of being located in GUO's home country.

\section{Results}

Columns (1) and (2) of Table 2 summarizes the results of the OLS and WLS estimates of the home bias from Equation (1). Results show some prima facie evidence of the bias: the mean exit rate in domestic subsidiaries of MNCs is significantly smaller than in foreign ones.

The bias further increases when we restrict the sample and consider only the MNCs having experienced at least a divestment from 2008 to 2014 (columns 3 and 4). The OLS estimates on the restricted sample (column 3) imply that the exit probability for domestic subsidiaries is 4.6 percentage points lower than for foreign ones, where the exit probability of foreign subsidiaries in these MNCs has been $17 \%$. This seems to suggest that the corporations more severely hit by the crisis preferred to close down foreign rather than domestic companies in order to remain

\footnotetext{
14 In so doing, we harmonized NAICS and NACE economic sector classifications using the conversion guidelines provided by Bureau van Djik. When the GUOs is not itself a company the dummy was set to zero.

15 Model (4) and (5) are examples of generalized linear mixed models, that generalize the linear mixed-effects model to non-Gaussian responses (see Rabe-Hesketh and Skrondal 2012, Ch.10). The random effects are not directly estimated as model parameters but are summarized according to the variance components.
} 
Table 2 Estimation results treating exit rates 2008-2014 in domestic and foreign subsidiaries of EU MNCs as paired samples matched at the GUO level

\begin{tabular}{lcccc}
\hline \hline & \multicolumn{2}{c}{ Whole sample } & \multicolumn{2}{c}{ MNCs with shutdowns } \\
\cline { 2 - 5 } & OLS & WLS & OLS & WLS \\
\hline Home bias & $-.00336^{* * *}$ & $-.00316^{* * *}$ & $-.0463^{* * *}$ & $-.00930^{* *}$ \\
& $(.00106)$ & $(.00073)$ & $(.0145)$ & $(.00466)$ \\
\hline Distinct GUOs & 11,232 & 11,232 & 814 & 814 \\
Observations & 22,464 & 22,464 & 1,628 & 1,628 \\
\hline \hline
\end{tabular}

Dependent variable: exit rate in domestic/foreign subsidiaries of each MNC. In Weighted Least Squares (WLS), the weights are given by the number of domestic/foreign companies in each MNC before the crisis.

${ }^{*} p$-value $<0.10,{ }^{* *} p$-value $<0.05,{ }^{* * *} p$-value $<0.01$.

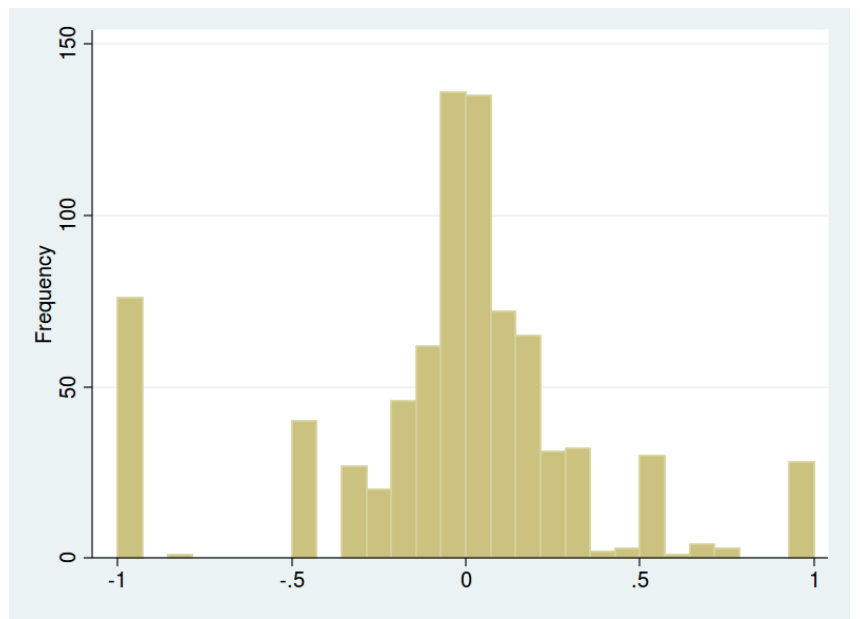

Fig. 1 Frequency histogram of the difference of exit rates in domestic vs. foreign subsidiaries in MNCs having experienced at least a closure from 2008 to $2014(\mathrm{~N}=814)$

competitive. The point estimate of the home bias decreases in the WLS estimates (almost 1\%), but it is still statistically significant.

Figure 1 shows the frequency histogram of the difference of exit rates between domestic and foreign subsidiaries of these MNCs, providing further mild evidence of a home bias. However, it is worth noting that, in spite of the fact that the t-test rejects the null of zero expected value (two-tailed $p$-value $=0.0015$ ), the Wilcoxon signed-rank test does not reject the null of the distribution being symmetric about zero $(p$-value $=0.28)$. Therefore, a further investigation is needed to confirm that MNCs prefer to dismiss foreign rather than domestic companies.

Although estimates in Table 2 control for the unobserved heterogeneity at the MNC level, they do not control for the other factors at the level of the individual subsidiary that could systematically affect the probability of divestment. This is something that can be done by estimating the individual exit Equation (3). Results are reported in Tables 3 and 4, which refer to the whole sample and to the sub-sample of MNCs that dismissed at least a subsidiary in the period, respectively. We estimated several specifications, adding progressively different controls. 
Table 3 Factors affecting the exit probability of companies belonging to MNCs in EU from 2008 to 2014

\begin{tabular}{|c|c|c|c|c|c|c|}
\hline & (1) & $(2)$ & $(3)$ & $(4)$ & $(5)$ & $(6)$ \\
\hline Home bias & $\begin{array}{c}-.00316^{* * *} \\
(.00073)\end{array}$ & $\begin{array}{c}-.00140^{*} \\
(.00078)\end{array}$ & $\begin{array}{l}-.00086 \\
(.00077)\end{array}$ & $\begin{array}{l}-.00096 \\
(.000757)\end{array}$ & $\begin{array}{l}.00019 \\
(.00076)\end{array}$ & $\begin{array}{c}.00016 \\
(.00074)\end{array}$ \\
\hline Age & & & $\begin{array}{c}-.000071^{* * *} \\
(.000021)\end{array}$ & $\begin{array}{c}-.000075^{* * *} \\
(.000021)\end{array}$ & $\begin{array}{l}-.000028 \\
(.000018)\end{array}$ & $\begin{array}{c}-.000031^{*} \\
(.000018)\end{array}$ \\
\hline $\mathrm{Age}^{2}$ & & & $\begin{array}{c}1.83 \mathrm{e}-07^{* * *} \\
(6.82 \mathrm{e}-08)\end{array}$ & $\begin{array}{c}1.89 \mathrm{e}-07^{* * *} \\
(6.98 \mathrm{e}-08)\end{array}$ & $\begin{array}{l}7.86 \mathrm{e}-08^{*} \\
(4.71 \mathrm{e}-08)\end{array}$ & $\begin{array}{l}8.26 \mathrm{e}-08^{*} \\
(4.81 \mathrm{e}-08)\end{array}$ \\
\hline GUO-firm same sector & & & $\begin{array}{l}.00206^{*} \\
(.00116)\end{array}$ & $\begin{array}{l}.00246^{* *} \\
(.00122)\end{array}$ & $\begin{array}{l}.000675 \\
(.00115)\end{array}$ & $\begin{array}{l}.000217 \\
(.00116)\end{array}$ \\
\hline Headquarter & & & & $\begin{array}{l}-.00119 \\
(.00096)\end{array}$ & & $\begin{array}{l}-.00180^{*} \\
(.00093)\end{array}$ \\
\hline Services & & & & $\begin{array}{l}-.000988 \\
(.000851)\end{array}$ & & $\begin{array}{l}-.00177^{* * *} \\
(.000890)\end{array}$ \\
\hline Small & & & & & $\begin{array}{c}-.00361^{* * *} \\
(.00095)\end{array}$ & $\begin{array}{c}-.00329^{* * *} \\
(.00093)\end{array}$ \\
\hline Medium & & & & & $\begin{array}{c}-.00751^{* * *} \\
(.00099)\end{array}$ & $\begin{array}{c}-.00717^{* * *} \\
(.00097)\end{array}$ \\
\hline Large & & & & & $\begin{array}{c}-.0109^{* * *} \\
(.00118)\end{array}$ & $\begin{array}{c}-.0106^{* * *} \\
(.00115)\end{array}$ \\
\hline Country dummies (26) & No & Yes & Yes & Yes & Yes & Yes \\
\hline Sector dummies (23) & No & No & Yes & No & Yes & No \\
\hline Distinct GUOs & 11,232 & 11,232 & 11,232 & 11,232 & 10,547 & 10,547 \\
\hline Observations & 132,120 & 132,120 & 129,945 & 129,945 & 93,937 & 93,937 \\
\hline
\end{tabular}

Table 4 Factors affecting the exit probability of companies belonging to EU MNCs having experienced at least an exit from 2008 to 2014

\begin{tabular}{|c|c|c|c|c|c|c|}
\hline & $\overline{(1)}$ & $\overline{(2)}$ & $\overline{(3)}$ & $\overline{(4)}$ & $\overline{(5)}$ & $(6)$ \\
\hline Home bias & $\begin{array}{c}-.00930^{* * *} \\
(.00206)\end{array}$ & $\begin{array}{c}-.00709^{* * *} \\
(.00228)\end{array}$ & $\begin{array}{c}-.00590^{* * *} \\
(.00225)\end{array}$ & $\begin{array}{c}-.00609^{* * *} \\
(.00223)\end{array}$ & $\begin{array}{c}.00057 \\
(.00221)\end{array}$ & $\begin{array}{l}.00014 \\
(.00218)\end{array}$ \\
\hline Age & & & $\begin{array}{l}-.0002^{* * *} \\
(.000053)\end{array}$ & $\begin{array}{c}-.000205^{* * * *} \\
(.000053)\end{array}$ & $\begin{array}{c}-.000088^{*} \\
(.000048)\end{array}$ & $\begin{array}{c}-.000094^{* *} \\
(.000047)\end{array}$ \\
\hline $\mathrm{Age}^{2}$ & & & $\begin{array}{l}4.46 \mathrm{e}-7^{* *} \\
(2.19 \mathrm{e}-7)\end{array}$ & $\begin{array}{l}4.35 \mathrm{e}-7^{*} \\
(2.24 \mathrm{e}-7)\end{array}$ & $\begin{array}{c}1.78 \mathrm{e}-7 \\
(1.13 \mathrm{e}-7)\end{array}$ & $\begin{array}{c}1.73 \mathrm{e}-7 \\
(1.16 \mathrm{e}-7)\end{array}$ \\
\hline GUO-firm same sector & & & $\begin{array}{l}.00421 \\
(.00270)\end{array}$ & $\begin{array}{l}.00495^{*} \\
(.00267)\end{array}$ & $\begin{array}{c}.00232 \\
(.00281)\end{array}$ & $\begin{array}{l}.00088 \\
(.00273)\end{array}$ \\
\hline Headquarter & & & & $\begin{array}{l}-.00430^{*} \\
(.00255)\end{array}$ & & $\begin{array}{l}-.00481^{*} \\
(.00280)\end{array}$ \\
\hline Services & & & & $\begin{array}{l}-.00292 \\
(.00216)\end{array}$ & & $\begin{array}{l}-.00374^{*} \\
(.00225)\end{array}$ \\
\hline Small & & & & & $\begin{array}{c}-.0120^{* * *} \\
(.0028)\end{array}$ & $\begin{array}{c}-.0111^{* * *} \\
(.0027)\end{array}$ \\
\hline Medium & & & & & $\begin{array}{c}-.0217^{* * * *} \\
(.0027)\end{array}$ & $\begin{array}{c}-.0207^{* * *} \\
(.0026)\end{array}$ \\
\hline Large & & & & & $\begin{array}{c}-.0291^{* * *} \\
(.0029)\end{array}$ & $\begin{array}{c}-.0280^{* * * *} \\
(.0028)\end{array}$ \\
\hline Country dummies (26) & No & Yes & Yes & Yes & Yes & Yes \\
\hline Sector dummies (23) & No & No & Yes & No & Yes & No \\
\hline Distinct GUOs & 814 & 814 & 814 & 814 & 762 & 762 \\
\hline Observations & 45,224 & 45,224 & 44,227 & 44,227 & 30,097 & 30,097 \\
\hline
\end{tabular}

Dependent variable: dummy equal to 1 if the company is not active in 2014 and 0 otherwise.

Heteroskedasticity-robust standard errors in parentheses.

${ }^{*} p$-value $<0.10,{ }^{* *} p$-value $<0.05,{ }^{* * *} p$-value $<0.01$. 
In particular, columns (1) of both the tables report the results without any control. They provide evidence of the home bias and, as expected, the sign and the magnitude of the bias are the same as in columns (2) and (4) of Table 2. ${ }^{16}$

In columns (2) of Tables 3 and 4 we introduce host country dummies to control for the common unobserved shocks that might have affected MNCs' divestment decisions at the country level. The introduction of such controls reduces the point estimate and the statistical significance of the home bias. This result points out that at least part of the observed "bias" is to be ascribed to the fact that divestment decisions are also driven by the overall economic prospects of the host country (Benito 1997; Berry 2013). Since in EU the countries more likely to be host countries, namely peripheral countries, faced the most severe and longest recession, not introducing country dummies leads to overestimate the "bias". ${ }^{17}$

Columns (3) show the estimates when sector controls and some firm-level characteristics are included. As for the latter, we considered firstly only the characteristics that allow us to use the whole sample in order to ensure the comparability of the results with those previously obtained. These variables include a dummy taking the value of 1 if the observed firm and its GUO operate in the same sector and the age of the observed unit. Results confirm the "liability of newness", i.e. the older the company, the lower the closure probability (e.g. Freeman et al. 1983; Dunne and Hughes 1994; Carroll and Hannan 2000), and suggest that horizontal FDI are more likely to be divested than vertical FDI, as indicated by the positive sign of the estimated coefficient. ${ }^{18}$

However, this effect does not seem to be robust since the coefficient turns out to be slightly significant only in the specifications that do not control for the firm size (columns 3 and 4). The inclusion of the latter control (columns 5 and 6) confirms the existence of the "liability of smallness" (the smaller the company, the higher the closure probability) as well as the existence of other possible factors affecting divestment decisions, like the potential business functions performed by the observed units, where units devoted to headquarter and administrative functions or operating in services are less likely to be dismissed.

The results are confirmed by the mixed-effects probit regressions. In particular, the estimates of the two-level probit models with random intercept (Table 5) and with random intercept and slope (Table 6) on the whole sample confirm the existence of the liabilities of newness and smallness. As far as the home bias is concerned, both the models lead to estimates of the average partial effect (APE) similar to the ones delivered by the LPM and the effect is statistically significant only in the specifications without controls for country-, sector- and/or firm-specific factors. The negative covariance between the constant and the home bias coefficient in the model with random intercept and slope (last row of Table 6) hints at the fact that the bias appears to be the stronger the higher the closure probability in

\footnotetext{
16 As discussed in Section 2, a WLS estimator at the MNC level with weights equal to the domestic/foreign number of subsidiaries produces the same point estimate of the home bias of the LPM estimated at the individual-company level (Equation 2).

17 We also controlled specifically for the GIIPS (Greece, Ireland, Italy, Portugal and Spain) countries, including a dummy for these countries in Equation (3) (alone and also interacted with $h$ ). Although the coefficient attached to the GIIPS dummy is positive and statistically significant (the exit rate has been on average higher in the GIIPS countries), the interaction term is not statistically significant and the estimate of the home bias stays about the same.

18 This finding is not in line with previous similar studies (e.g. Benito 1997), which however have a narrower perspective than the present study.
} 
Table 5 Mixed-effects probit regressions: two-level model with random intercept

\begin{tabular}{|c|c|c|c|c|c|c|}
\hline & (1) & $\overline{(2)}$ & 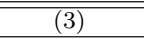 & $(4)$ & 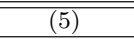 & 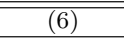 \\
\hline Home bias & $\begin{array}{c}-.12952^{* * * *} \\
(.02422)\end{array}$ & $\begin{array}{l}-.03045 \\
(.02777)\end{array}$ & $\begin{array}{l}-.03072 \\
(.02896)\end{array}$ & $\begin{array}{l}-.02194 \\
(.02859)\end{array}$ & $\begin{array}{l}.00413 \\
(.00394)\end{array}$ & $\begin{array}{l}.04243 \\
(.03877)\end{array}$ \\
\hline Age & & & $\begin{array}{c}-.00390^{* * *} \\
(.00092)\end{array}$ & $\begin{array}{c}-.00436^{* * *} \\
(.00091)\end{array}$ & $\begin{array}{c}-.00301^{* *} \\
(.00131)\end{array}$ & $\begin{array}{c}-.00332^{* *} \\
(.00129)\end{array}$ \\
\hline $\mathrm{Age}^{2}$ & & & $\begin{array}{c}6.95 \mathrm{e}-06^{* * *} \\
(3.21 \mathrm{e}-06)\end{array}$ & $\begin{array}{l}7.20 \mathrm{e}-06^{* *} \\
(3.12 \mathrm{e}-06)\end{array}$ & $\begin{array}{c}4.84 \mathrm{e}-06 \\
(5.18 \mathrm{e}-06)\end{array}$ & $\begin{array}{c}4.90 \mathrm{e}-06 \\
(4.91 \mathrm{e}-06)\end{array}$ \\
\hline GUO-firm same sector & & & $\begin{array}{l}.05779^{* *} \\
(.04109)\end{array}$ & $\begin{array}{l}.07705^{* *} \\
(.03880)\end{array}$ & $\begin{array}{c}.01579 \\
(.05696)\end{array}$ & $\begin{array}{l}.01691 \\
(.05544)\end{array}$ \\
\hline Headquarter & & & & $\begin{array}{l}-.03554 \\
(.04590)\end{array}$ & & $\begin{array}{l}-.02393 \\
(.07631)\end{array}$ \\
\hline Services & & & & $\begin{array}{l}-.03631 \\
(.02781)\end{array}$ & & $\begin{array}{l}-.07232^{*} \\
(.03692)\end{array}$ \\
\hline Small & & & & & $\begin{array}{c}-.15526^{* * *} \\
(.04047)\end{array}$ & $\begin{array}{c}-.15188^{* * *} \\
(.03997)\end{array}$ \\
\hline Medium & & & & & $\begin{array}{c}-.29523^{* * *} \\
(.04737)\end{array}$ & $\begin{array}{c}-.29049^{* * *} \\
(.04637)\end{array}$ \\
\hline Large & & & & & $\begin{array}{c}-.49813^{* * *} \\
(.06674) \\
\end{array}$ & $\begin{array}{c}-.48895^{* * * *} \\
(.06576)\end{array}$ \\
\hline Country dummies & No & Yes & Yes & Yes & Yes & $\overline{\text { Yes }}$ \\
\hline Sector dummies & No & No & Yes & No & Yes & No \\
\hline Home bias (APE) & $\begin{array}{c}-.00327^{* * *} \\
(.00063)\end{array}$ & $\begin{array}{l}-.00073 \\
(.00067)\end{array}$ & $\begin{array}{l}-.00070 \\
(.00066)\end{array}$ & $\begin{array}{l}-.00049 \\
(.00064)\end{array}$ & $\begin{array}{c}.00070 \\
(.00066)\end{array}$ & $\begin{array}{c}.00072 \\
(.00066)\end{array}$ \\
\hline Clusters (GUOs) & 11,232 & 11,231 & 11,231 & 11,231 & 10,537 & 10,537 \\
\hline Observations & 132,120 & 131,209 & 128,924 & 129,038 & 93,108 & 93,191 \\
\hline
\end{tabular}

Dependent variable: dummy equal to 1 if the company is not active in 2014 and 0 otherwise.

$\mathrm{APE}=$ Average Partial Effect. ${ }^{*} p$-value $<0.10,{ }^{* *} p$-value $<0.05,{ }^{* * *} p$-value $<0.01$.

Table 6 Mixed-effects probit regressions: two-level model with random intercept and slope

\begin{tabular}{|c|c|c|c|c|c|c|}
\hline & $\overline{(1)}$ & $\overline{(2)}$ & $(3)$ & $(4)$ & $(5)$ & $(6)$ \\
\hline Home bias & $\begin{array}{c}-.19074^{* * *} \\
(.04958)\end{array}$ & $\begin{array}{l}-.01418 \\
(.04608)\end{array}$ & $\begin{array}{l}-.01066 \\
(.04599)\end{array}$ & $\begin{array}{c}.00428 \\
(.04670)\end{array}$ & $\begin{array}{c}.01428 \\
(.05580)\end{array}$ & $\begin{array}{c}.01416 \\
(.05573)\end{array}$ \\
\hline Age & & & $\begin{array}{c}-.00394^{* * *} \\
(.00093)\end{array}$ & $\begin{array}{c}-.00440^{* * *} \\
(.00092)\end{array}$ & $\begin{array}{c}-.00292^{*} \\
(.00132)\end{array}$ & $\begin{array}{c}-.00326^{* *} \\
(.00131)\end{array}$ \\
\hline $\mathrm{Age}^{2}$ & & & $\begin{array}{c}7.24 \mathrm{e}-06^{* *} \\
(3.22 \mathrm{e}-06)\end{array}$ & $\begin{array}{c}7.47 \mathrm{e}-06^{* *} \\
(3.13 \mathrm{e}-06)\end{array}$ & $\begin{array}{c}5.06 \mathrm{e}-06 \\
(5.11 \mathrm{e}-06)\end{array}$ & $\begin{array}{c}5.16 \mathrm{e}-06 \\
(4.86 \mathrm{e}-06)\end{array}$ \\
\hline GUO-firm same sector & & & $\begin{array}{c}.05474 \\
(.04212)\end{array}$ & $\begin{array}{l}.07378^{*} \\
(.03989)\end{array}$ & $\begin{array}{c}.00952 \\
(.05783)\end{array}$ & $\begin{array}{c}.01135 \\
(.05631)\end{array}$ \\
\hline Headquarter & & & & $\begin{array}{l}-.03439 \\
(.04679)\end{array}$ & & $\begin{array}{l}-.02385 \\
(.07744)\end{array}$ \\
\hline Services & & & & $\begin{array}{l}-.03954 \\
(.02836)\end{array}$ & & $\begin{array}{c}-.07394^{* *} \\
(.03737)\end{array}$ \\
\hline Small & & & & & $\begin{array}{c}-.15876^{* * *} \\
(.04097)\end{array}$ & $\begin{array}{c}-.15590^{* * *} \\
(.04049)\end{array}$ \\
\hline Medium & & & & & $\begin{array}{c}-.29688^{* * *} \\
(.04788)\end{array}$ & $\begin{array}{c}-.29338^{* * *} \\
(04689)\end{array}$ \\
\hline Large & & & & & $\begin{array}{c}-.50274^{* * *} \\
(.06753)\end{array}$ & $\begin{array}{c}-.49423^{* * *} \\
(.06655)\end{array}$ \\
\hline Country dummies & No & Yes & Yes & Yes & Yes & Yes \\
\hline Sector dummies & No & No & Yes & No & Yes & No \\
\hline Home bias (APE) & $\begin{array}{c}-.00271^{* * *} \\
(.00078)\end{array}$ & $\begin{array}{c}-.00047 \\
(.00077)\end{array}$ & $\begin{array}{l}-.00050 \\
(.00075)\end{array}$ & $\begin{array}{c}-.00032 \\
(.00074)\end{array}$ & $\begin{array}{c}.00092 \\
(.00072) \\
\end{array}$ & $\begin{array}{c}.00094 \\
(.00071) \\
\end{array}$ \\
\hline Clusters (GUOs) & 11,232 & 11,231 & 11,231 & 11,231 & 10,537 & 10,537 \\
\hline Observations & 132,120 & 131,209 & 128,924 & 129,038 & 93,108 & 93,191 \\
\hline $\operatorname{Var}($ home bias) & $\begin{array}{c}.49660 \\
(.06865)\end{array}$ & $\begin{array}{c}.31237 \\
(.06121)\end{array}$ & $\begin{array}{c}.28345 \\
(.05683)\end{array}$ & $\begin{array}{c}.29113 \\
(.05808)\end{array}$ & $\begin{array}{c}.20632 \\
(.07900)\end{array}$ & $\begin{array}{c}.21643 \\
(.08042)\end{array}$ \\
\hline Cov(home bias, const) & $\begin{array}{c}-.20561^{* * *} \\
(.04508) \\
\end{array}$ & $\begin{array}{c}-.15924^{* * *} \\
(.04387) \\
\end{array}$ & $\begin{array}{c}-.14804^{* * *} \\
(.04227) \\
\end{array}$ & $\begin{array}{c}-.15570^{* * *} \\
(.04371) \\
\end{array}$ & $\begin{array}{r}-.08240 \\
(.05018) \\
\end{array}$ & $\begin{array}{r}-.08682^{*} \\
(.05102) \\
\end{array}$ \\
\hline
\end{tabular}

Dependent variable: dummy equal to 1 if the company is not active in 2014 and 0 otherwise.

$\mathrm{APE}=$ Average Partial Effect. ${ }^{*} p$-value $<0.10,{ }^{* *} p$-value $<0.05,{ }^{* * *} p$-value $<0.01$. 
Table 7 Mixed-effects probit regressions: two-level model with random intercept and slope for companies belonging to EU MNCs having experienced at least an exit from 2008 to 2014

\begin{tabular}{|c|c|c|c|c|c|c|}
\hline & $(1)$ & $\overline{(2)}$ & $\overline{(3)}$ & $(4)$ & $(5)$ & $(6)$ \\
\hline Home bias & $\begin{array}{c}-.09813^{* *} \\
(.04861)\end{array}$ & $\begin{array}{c}-.09617^{* *} \\
(.04572)\end{array}$ & $\begin{array}{l}-.07547 \\
(.04763)\end{array}$ & $\begin{array}{l}-.09096^{*} \\
(.04727)\end{array}$ & $\begin{array}{c}.02144 \\
(.06048)\end{array}$ & $\begin{array}{l}-.00768 \\
(.05961)\end{array}$ \\
\hline Age & & & $\begin{array}{c}-.00506^{* * *} \\
(.00102)\end{array}$ & $\begin{array}{c}-.00495^{* * *} \\
(.00100)\end{array}$ & $\begin{array}{c}-.00389^{* * *} \\
(.00149)\end{array}$ & $\begin{array}{c}-.00371^{* *} \\
(.00148)\end{array}$ \\
\hline $\mathrm{Age}^{2}$ & & & $\begin{array}{l}8.35 \mathrm{e}-06^{* *} \\
(3.46 \mathrm{e}-06)\end{array}$ & $\begin{array}{l}7.68 \mathrm{e}-06^{* *} \\
(3.45 \mathrm{e}-06)\end{array}$ & $\begin{array}{c}5.84 \mathrm{e}-06 \\
(5.94 \mathrm{e}-06)\end{array}$ & $\begin{array}{c}5.05 \mathrm{e}-06 \\
(6.05 \mathrm{e}-06)\end{array}$ \\
\hline GUO-firm same sector & & & $\begin{array}{c}.00782 \\
(.04762)\end{array}$ & $\begin{array}{l}.00572 \\
(.04410)\end{array}$ & $\begin{array}{l}-.01526 \\
(.06862)\end{array}$ & $\begin{array}{l}-.04630 \\
(.06581)\end{array}$ \\
\hline Headquarter & & & & $\begin{array}{l}-.06323 \\
(.05089)\end{array}$ & & $\begin{array}{c}-.05851 \\
(.08741)\end{array}$ \\
\hline Services & & & & $\begin{array}{c}-.07153^{* *} \\
(.03259)\end{array}$ & & $\begin{array}{c}-.12459^{* * *} \\
(.04408)\end{array}$ \\
\hline Small & & & & & $\begin{array}{c}-.21281^{* * *} \\
(.04816)\end{array}$ & $\begin{array}{c}-.19649^{* * *} \\
(.04757)\end{array}$ \\
\hline Medium & & & & & $\begin{array}{c}-.40890^{* * *} \\
(.05501)\end{array}$ & $\begin{array}{c}-.38620^{* * *} \\
(.05375)\end{array}$ \\
\hline Large & & & & & $\begin{array}{c}-.70642^{* * *} \\
(.07555) \\
\end{array}$ & $\begin{array}{c}-.68164^{* * *} \\
(.07395) \\
\end{array}$ \\
\hline Country dummies & No & Yes & Yes & Yes & Yes & Yes \\
\hline Sector dummies & No & No & Yes & No & Yes & No \\
\hline Home bias (APE) & $\begin{array}{l}-.00444 \\
(.00796)\end{array}$ & $\begin{array}{c}-.01142^{*} \\
(.00624)\end{array}$ & $\begin{array}{l}-.00688 \\
(.00595) \\
\end{array}$ & $\begin{array}{c}-.00908 \\
(.00608) \\
\end{array}$ & $\begin{array}{c}.00688 \\
(.00522) \\
\end{array}$ & $\begin{array}{c}.00576 \\
(.00536)\end{array}$ \\
\hline Clusters (GUOs) & 814 & 814 & 814 & 814 & 762 & 762 \\
\hline Observations & 45,224 & 44,914 & 43,875 & 43,919 & 29,783 & 29,821 \\
\hline Var(home bias) & $\begin{array}{c}.84613 \\
(.15725)\end{array}$ & $\begin{array}{c}.53367 \\
(.10787)\end{array}$ & $\begin{array}{c}.58481 \\
(.11726)\end{array}$ & $\begin{array}{c}.56930 \\
(.11725)\end{array}$ & $\begin{array}{c}.51958 \\
(.15841)\end{array}$ & $\begin{array}{c}.48263 \\
(.15268)\end{array}$ \\
\hline Cov(home bias, const) & $\begin{array}{c}-.36969^{* * *} \\
(.09158)\end{array}$ & $\begin{array}{c}-.27652^{* * *} \\
(.06891)\end{array}$ & $\begin{array}{c}-.28840^{* * *} \\
(.07295)\end{array}$ & $\begin{array}{c}-.28460^{* * *} \\
(.07363)\end{array}$ & $\begin{array}{c}-.20350^{* *} \\
(.09674)\end{array}$ & $\begin{array}{l}-.17655^{*} \\
(.09253)\end{array}$ \\
\hline
\end{tabular}

Dependent variable: dummy equal to 1 if the company is not active in 2014 and 0 otherwise

$\mathrm{APE}=$ Average Partial Effect. ${ }^{*} p$-value $<0.10,{ }^{* *} p$-value $<0.05,{ }^{* * *} p$-value $<0.01$

the corporate group the company belongs to, although this negative covariance (and its statistical significance) decreases by including controls for the company size.

All the previous results are confirmed when the two-level probit model (with random intercept and slope) is estimated on the subsample of companies belonging to EU MNCs that have experienced at least an exit from 2008 to 2014 (Table 7). In particular, the average partial effect of the home bias is not statistically significant and the point estimate of the effect becomes positive (whereas instead the negative covariance between the constant and the home bias coefficient decreases), when the liabilities of newness and smallness are properly taken into account.

Thus, it seems that foreign subsidiaries have been dismissed because they were smaller and younger than the domestic counterparts, and there is no strong evidence that divestment decisions of European MNCs are driven by the will to protect domestic units, as these decisions rather depend mainly on firm-specific factors.

\section{Conclusions}

By using data on the operations of European MNCs in the EU28 during the economic crisis, we analyzed the empirical evidence on divestment decisions of MNCs, considering all possible locations and comparing whether and to what extent domestic subsidiaries have been less likely to be shutdown or otherwise dismissed compared with foreign subsidiaries during the recent economic crisis. 
This is in contrast with the existing literature, that does not investigate whether intra-national and cross-boundary closures respond to the same factors.

Our findings show that, despite some prima facie evidence of a home bias in divestment decisions, i.e. the idea that domestic subsidiaries are less likely to be dismissed than foreign ones in MNCs, the bias disappears when controlling for country-, sector- and firm-specific effects.

Our results show that divestment is the product of complex restructuring strategies within MNCs, and it does not seem to be affected by "emotional elements" and, thus, systematically biased. Consequently, foreign divestment is not either more likely or easier than domestic one, even during economic downturns, when divestment may become the only viable solution to maintain acceptable levels of efficiency within corporations, and social and political pressures might increase both at home and abroad.

From a policy perspective, our findings have important implications for countries pursuing active FDI promotion policies, for these policies could exacerbate the impact of economic recessions if foreign corporations were more likely to divest in the domestic economy than local companies.

In this regard, there are other aspects that are worth studying, such as, for instance, the possible differences in the determinants of divestment decisions of MNCs and the other companies. These extensions are all feasible, and will further improve the present knowledge on MNCs' divestment processes.

\section{References}

Alfaro, L., and A. Rodriguez-Clare. 2004. Multinationals and linkages: an empirical investigation. Economia 4 (2): 13-69.

Belberdos, R., and J. Zou. 2006. Foreign investment, divestment and relocation by Japanese electronics firms in East Asia. Asian Economic Journal 20 (1): 1-27.

Benito, G. 2005. Divestment and international business strategy. Journal of Economic Geography 5 (2): $235-251$.

Benito, Gabriel R. G. 1997. Divestment of foreign production operations. Applied Economics 29 (10): 1365-1378.

Bernard, A. B., B. Jensen, S. Redding, and P Schott. 2007. Firms in international trade. Journal of Economic Perspectives 21 (3): 105-130.

Berry, Heather. 2013. When do firms divest foreign operations? Organization Science 24 (1): $246-261$.

Boddewyn, Jean J. 1979. Foreign divestment: Magnitude and factors. Journal of International Business Studies 10 (1): 21-27.

Boddewyn, Jean J. 1983a. Foreign and domestic divestment and investment decisions: Like or unlike? Journal of International Business Studies 14 (3): 23-35.

Boddewyn, Jean J. 1983b. Foreign direct divestment theory: Is it the reverse of FDI theory? Weltwirtschaftliches Archiv 119 (2): 345-355.

Branstetter, Lee. 2006. Is Foreign Direct Investment a channel of knowledge spillovers? evidence from Japan's FDI in the United States. Journal of International Economics 68 (2): 325-344.

Bruderl, Josef, and Rudolf Schussler. 1990. Organizational mortality: The liabilities of newness and adolescence. Administrative Science Quarterly 35 (3): 530.

Carroll, G. R., and M. T. Hannan. 2000. The demography of corporations and industries. Princeton NJ: Princeton University Press.

Chen, Tain-Jy, and Grace Wu. 1996. Determinants of divestment of FDI in Taiwan. Weltwirtschaftliches Archiv 132 (1): 172-184.

Demidenko, E. 2004. Mixed models: Theory and applications. Hoboken, NJ: Wiley.

Doms, M., and J. Jensen. 1998. Comparing wages, skills and productivity between domestically and foreign-owned manufacturing establishments in the United States. In Geography and 
ownership as bases for economic accounting, eds. R. Baldwin, R. Lipsey, and J. Richardson, 235-255. Chicago: Chicago University Press.

Driffield, N., and M. Noor. 1999. Foreign Direct Investment and local input linkages in Malaysia. Transnational Corporations 8 (3): 1-23.

Dunne, Paul, and Alan Hughes. 1994. Age, size, growth and survival: UK companies in the 1980s. The Journal of Industrial Economics 42 (2): 115-140.

Freeman, J., G. Carroll, and M. T. Hannan. 1983. The liability of newness: Age dependency in organizational death rates. American Sociological Review 48 (5): 692-710.

Geroski, P. A. 1995. What do we know about entry? International Journal of Industrial Organization 13 (4): 421-440.

Girma, Sourafel, and Holger Görg. 2007. Multinationals productivity advantage: Scale or technology? Economic Inquiry 45 (2): 350-362.

Godart, O., Holger Görg, and A. Hanley. 2012. Surviving the crisis: Foreign multinationals vs. domestic firms. The World Economy 35 (10): 1305-1321.

Görg, H., and D. Greenaway. 2004. Much ado about nothing? Do domestic firms really benefit from Foreign Direct Investment? The World Bank Research Observer 19 (2): 171-197.

Görg, H., and E. Strobl. 2003. Footloose multinationals? The Manchester School 71 (1): 1-19.

Görg, Holger, and Eric Strobl. 2001. Multinational companies and productivity spillovers: A meta-analysis. The Economic Journal 111 (475): 723-739.

Harrigan, K. R. 1981. Deterrents to divesture. Academy of Management Journal 24 (2): 302-323.

Helpman, E., M. J. Melitz, and S. R. Yeaple. 2004. Export versus FDI with heterogeneous firms. The American Economic Review 94 (1): 300-316.

Honjo, Y. 2000. Business failure of new firms: an empirical analysis using a multiplicative hazards model. International Journal of Industrial Organization 18: 557-574.

Jovanovic, B. 1982. Selection and evolution of industry. Econometrica 50 (3): 25-43.

Mahmood, T. 2000. Survival of newly founded business: a log-logistic model approach. Small Business Economics 14: 223-237.

Mata, J., and P. Portugal. 2002. The survival of new domestic and foreign-owned firms. Strategic Management Journal 23 (4): 323-343.

Mata, J., and P. Portugal. 2004. Patterns of entry, post-entry growth and survival. Small Business Economics 22: 283-298.

McDermott, M. C. 2010. Foreign divestment. the neglected area of international business. International Studies of Management and Organizations 40 (4): 37-53.

Norbak, P., A. Tekin-Koru, and A. Waldkirch. 2015. Multinational firms and plant divesture. Review of International Economics 23 (5): 811-45.

Pakes, A., and R. Ericson. 1998. Empirical implications of alternative models of firm dynamics. Journal of Economic Theory 79 (1): 1-45.

Rabe-Hesketh, S., and A. Skrondal. 2012. Multilevel and longitudinal modeling using Stata, 3rd edn. College Station, TX: Stata Press.

Richbell, S., and H. Watts. 2000. Plant closure in multiplant manufacturing firms: Adding an international perspective. Management Decision 38 (2): 80-89.

Soule, S., A. Swaminathan, and L. Tihanyi. 2014. The diffusion of foreign divestment from Burma. Strategic Management Journal 35 (7): 1032-1052.

Stinchcombe, A. L. 1965. Social structure and organizations. In Handbook of organizations, ed. J. G. March. Chicago: Rand McNally.

UNCTAD. 2015. World investment report 2015. Geneva: United Nation Press.

van Pottelsberghe de la Potterie, Bruno, and F. Lichtenberg. 2001. Does Foreign Direct Investment transfer technology across borders? Review of Economics and Statistics 83 (3): 490-497.

Wooldridge, Jeffrey M. 2010. Econometric analysis of cross-section and panel-data, 2nd edn. Cambridge, MA: MIT Press. 